\title{
Utilization of Power Setting in Monopolar Electrosurgery Unit With Additional Blend Modes
}

\author{
Muhammad Roni Setiawan, Tri Bowo Indrato, Triana Rahmawati \\ Department of Electromedical Engineering Poltekkes Kemenkes, Surabaya \\ Jl. Pucang Jajar Timur No. 10, Surabaya, 60245, Indonesia \\ mronis3031@gmail.com,Tribowo.tem81@gmail.com, triana@poltekkesdepkes-sby.ac.id,
}

\begin{tabular}{l}
\hline \multicolumn{1}{c}{ Article Info } \\
\hline Article History: \\
Received May 15, 2020 \\
Revised Nov 14, 2020 \\
Accepted Nov 25, 2020
\end{tabular}

Keywords:

Electrosurgery Unit, tissue, frequency, power

\begin{abstract}
Electrosurgery unit has the purpose of damaging certain body tissues by heating the tissue. In this study there are several modes and also power selection. The contribution of this research is to design the power management and also the addition of several modes for the surgical process. Electrosurgery Unit involves the use of IC CMOS 4069 as a frequency generator. The frequency output is set at 250 $\mathrm{KHz}$ and then passed on to the pulse regulator circuit and controlled by using Arduino and then forwarded to the inverter circuit which functions to increase the voltage and output in the form of power. Modules are calibrated using ESU Analyzer. This module is equipped with a selection of LOW, MEDIUM, and HIGH power. And also there are some additional modes including Blend 1 and Blend 2. After the measurement is carried out, the voltage values obtained at the setting of low, medium high, on the inverter input with a value on Blend 1 mode low $80 \mathrm{~V}$ with an error of $0.84 \%$, Medium 90 $\mathrm{V}$ with error $0.84 \%$, High $104 \mathrm{~V}$ with an error of $0.81 \%$, in Blend 2 mode low $84 \mathrm{~V}$ with an error of $0.83 \%$, Medium $86 \mathrm{~V}$ with a error of $0.85 \%$, High $105 \mathrm{~V}$ with an error of $0.81 \%$, the Cutting mode is low $162 \mathrm{~V}$ with an error of $2.88 \%$, medium $172 \mathrm{~V}$ with an error of $3.03 \%$, High $192 \mathrm{~V}$ with an error of $2.86 \%$. The measurement shows an error of less than $1 \%$ for Blend 1 and Blend 2 modes while cutting is less than $3 \%$. The results of this study can be implemented in order to minimize errors due to lack of power settings and mode selection during surgery.
\end{abstract}

\author{
Corresponding Author: \\ Tri Bowo Indrato \\ Tribowo.tem81@gmail.com \\ Department of Medical Electronics Engineering Technology \\ Poltekkes Kemenkes Surabaya
}

This work is an open access article and licensed under a Creative Commons Attribution-ShareAlike 4.0 International License (CC BY-SA 4.0).

\section{INTRODUCTION}

In the use of electrosurgery requires an understanding of human body tissues and appropriate power and mode settings to avoid the effects of damage to body tissues [1]. according to research the most basic things that make electrosurgery dangerous is one of them due to lack of understanding of the technology because the monopolar current generated is greater and will spread more widely throughout the body than by bipolar therefore the correct power and mode settings are needed for reduce the risk of injury [2][3]. The heat generated by electrosurgery can also have an impact on the network if the tissue implant is very sensitive to heat because even a little current and voltage passing through the network can damage the network, therefore power management is needed [4]. Understanding how the electric current through the body can help doctors prevent unexpected medical accidents because each part of the body has a different resistance [2], but with the power regulation and cutting mode, each cutting can be done by calculating the resistance of each tissue without damaging another network. An electric scalpel uses the principle of electric charge jumps in tissue surgery, or electrode contact with tissue is not required. With the effect of stepping electrons that burn tissue, the results of surgery will be more sterile [4]. Through understanding the output characteristics of electrosurgery will enable surgeons to more effectively vary the power output on the device, so that power selection settings will not have an impact or negatively affect tissue effects [5][6]. Electrosurgery is a tool used by surgeons to cut tissue and coagulate or to block blood flow and benefits that are not available with standard cold steel scalpels [7] [8][9][10]. The lack of mode is also a factor that is less than the surgical process, therefore variations in modes other than cutting and coagulation are very necessary to match the surgical process to be performed, and also with good power management. In line with technological advances making Electrosurgical is required to be used during the surgical process [11][12]. The frequency range commonly used ranges from $300 \mathrm{kHz}$ to $2.5 \mathrm{MHz}$ 
[13][14]. ESU operation is divided into 2 (two) modes, namely bipolar and monopolar. Bipolar mode is commonly used in minor surgery for coagulation (freezing) processes. A tweezers-shaped electrode is used to clamp unwanted tissue, then a high-frequency electric current flows from the tip of the electrode across the network and then to the other end of the electrode [15]. The use of a continuous waveform causes evaporation or cutting of tissue. The continuous waveform causes very rapid heating. By using an intermittent waveform (cut into pieces), more heat will be generated. On the other hand there are also the effects caused including unwanted heating effects that occur around the tissue that is dissected [16][17]. Using a constant waveform, such as "cutting", the surgeon is able to vaporize or cut tissue when the resulting voltage is high enough [18]. In monopolar ESU there are two basic wave forms that form two effects on very different tissues, namely pure cut and coagulation, both of which work in the same frequency and power, thus maintaining constant cutting and freezing [19].

This electrosurgery unit was made in 2000 by Albert where it only uses a frequency generator and pulse control system[20], and in 2009 Ronald made an electrosurgery unit which only observed the impedance caused by the surgical process in a network[21].

Based on the literature study description above, there are several things that need to be developed, namely the mode used, the researcher will design the cutting mode, coagulation, blend 1 , blend 2 , and blend 3 , because with the addition of modes can also minimize unwanted tissue damage during the surgical process, here researchers also use the selection of low, medium, and high power, this is also very important in the surgical process because it can help doctors to minimize the effects.

\section{MATERIALS AND METHODS}

\section{A. Experimental Setup}

In this study there are 3 modes, the first is cutting using $100 \%$ on duty cycle, the second is Blend 1 using $60 \%$ on $40 \%$ off duty cycle, and the third Blend 2 uses $50 \%$ on $50 \%$ off duty cycle, these three modes use low, medium, and high power settings, and uses the output of a frequency generator of $250 \mathrm{Khz}$.

\section{B. Materials and Device}

This study uses CMOS ICs (CD4069B, Texas Instrument, America) as high frequency generators, MOC (4N35, Agilent Technologies, America), regulator circuits or MOSFET drivers (740B, Fairchild Semiconductor, America) as AB type current amplifiers, ferrite type transformers : 42-M58802P01 as a voltage amplifier before entering the electrode. Microcontrollers (Nano, Arduino, Italy) are used as microcontrollers to regulate PWM output and power selection. IC frequency to voltage (LM2907, Texas Instrument, USA) to convert frequency to voltage. Using a Digital Oscilloscope (Textronic, DPO2012, Taiwan) is used to measure and regulate the output of a frequency generator.

\section{Trial}

In this study the measurements of all series were carried out using a digital oscilloscope.

\section{The Diagram Block}

When the switch is on then the input voltage from the PLN to the switch to activate the DC power supply, then the whole series will get a voltage from the DC supply. The input comes from the foot switch which functions as a switch to perform surgery with cutting and blend modes with the buzzer indicator sounding in addition to using the push button found on the hand piece. Next, the cutting and blend button functions as a mode regulator on ESU. The power selection button is used to adjust power via the microcontroller as we wish and then it will be displayed on the character LCD display for cutting mode power selection. Next to set the pulse or duty cycle in coagulate mode and blend mode, there is a pulse control block that is set through the microcontroller. For cutting duty cycle that is $100 \%$ on, blend 1 duty cycle that is $60 \%$ on, and blend 2 duty cycle $50 \%$ on.

Because the surgery process uses a high frequency and has been determined, there is a block generator circuit that produces a high frequency, the oscillator. From the oscillator block then entered in the pulse regulator block and will be processed in the driver block that has been done before the power settings. Then after processing through the driver block will then enter the ferrite transformer circuit. Ferrite transformer in the above series of blocks functions as an increase in the output voltage of the driver. Then the output of the ferrite transformer will enter the passive electrode and can be used for the surgical process. (Fig. 1).

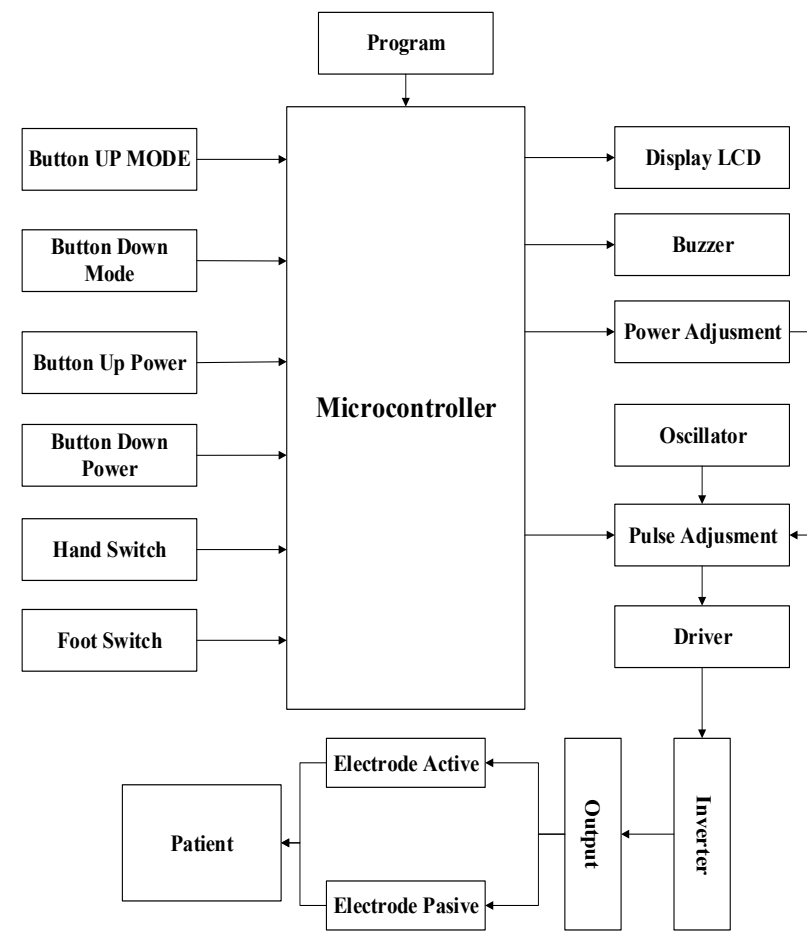

Fig 1. The diagram block of Electrosurgery Unit Monopolar 


\section{E. The Flowchart}

The flow chart proposed metod in Fig. 2 When the switch is on, the character LCD screen will start to be initialized. On the LCD screen the characters will display the power selection parameters in the cutting and blend mode. There are buttons that are low, medium and high which function to choose the power regulator which will then be displayed on the LCD character screen for cutting mode. When the foot switch is pressed the tool will work with the appearance of power on the LCD character screen complete.

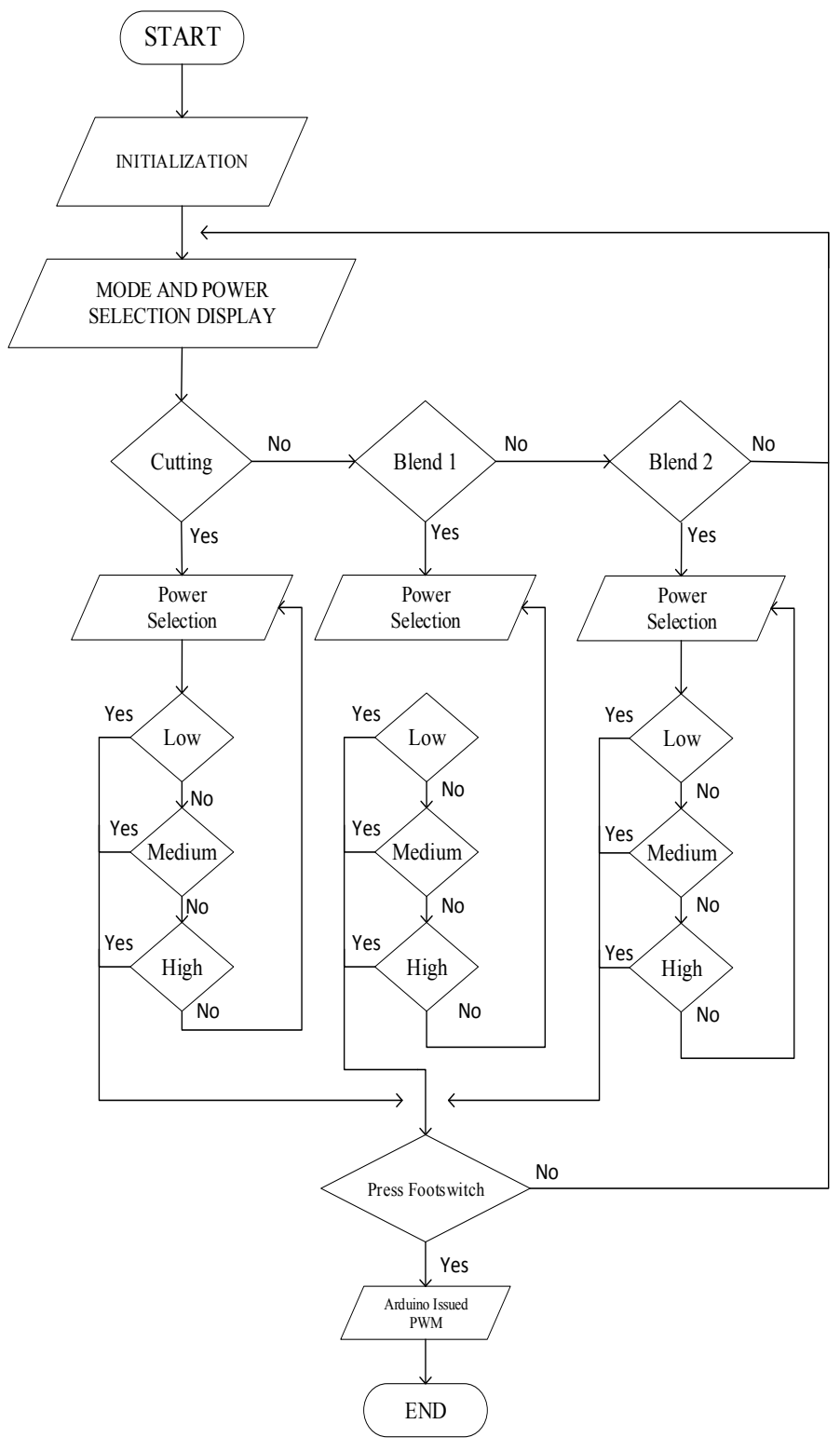

Fig 2. The Flowchart of Electrosurgery Unit Monopolar

\section{F. Circuit}

\section{1) Circuit of Oscillator}

In Fig. 3 the $250 \mathrm{Khz}$ oscillator circuit is the main pulse generator that works continuously. In this design the author uses NOT gate with IC CMOS CD 4069 as a high-frequency generator that will be used in this monopolar electrosurgery unit. High frequency used is $250 \mathrm{KHz}$. These pulses are square / square pulses. The oscillator circuit with NOT gate is also called Schmitt Trigger. The output is in the form of a rectangular pulse with the output condition switching from high to low and returning to high condition.

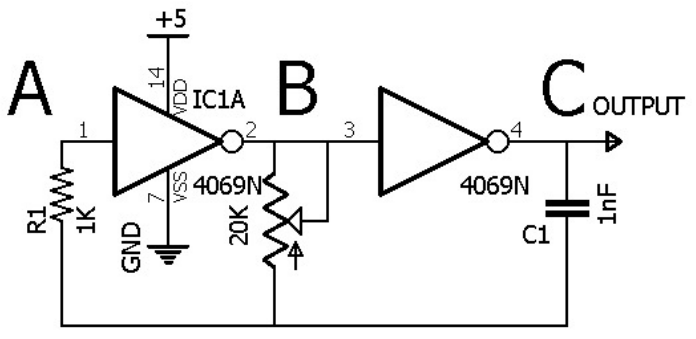

Fig 3. Circuit of oscillator

\section{2) The Power Regulator Driver Circuit}

The power regulator driver circuit in Fig. 4, This circuit will combine the power that has been regulated by the power regulator with the frequency that has been set by the pulse (dutycycle) by the pulse regulator circuit with the IRF540 mosfet refrigerator.

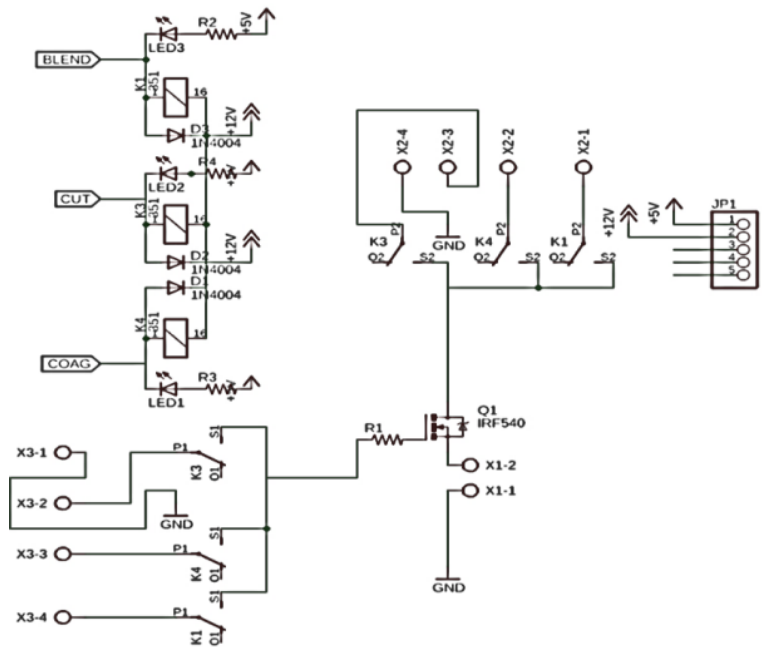

Fig 4. The power regulator driver circuit

\section{3) The pulse control circuit}

The pulse regulating circuit in Fig. 5 is a circuit that functions to adjust the shape of the main pulse, which was originally continuous to be non-continuous because it is cut by a pulse with a working cycle of $100 \%$ on cutting, and $60 \%$ on $40 \%$ off for blend 1 , and $50 \%$ on $50 \%$ off on blend 2 . To 
adjust the duty cycle used by the PWM generated by the microcontroller to control the $4503 \mathrm{~N}$ ic.

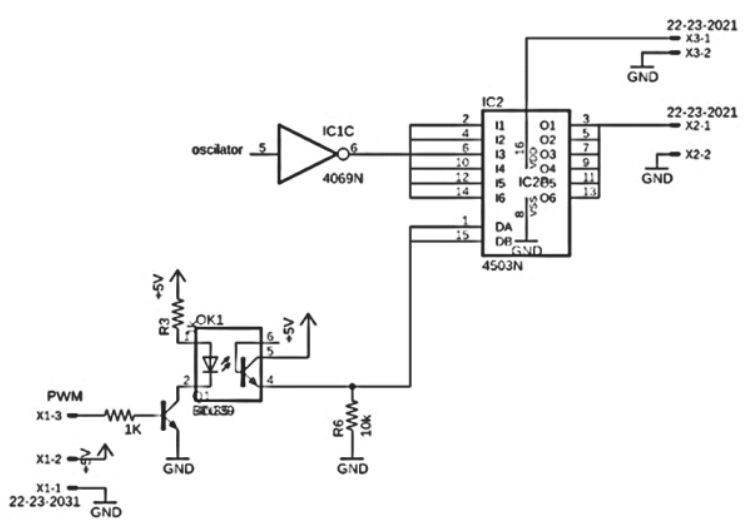

Fig 5. The pulse control circuit

\section{4) Power Management Circuit}

The power Management circuit in Fig.6 is a circuit that functions to regulate the output frequency amplitude of the transformer. With IC LM2907 as a frequency converter to voltage. The frequency is controlled through a microcontroller circuit.

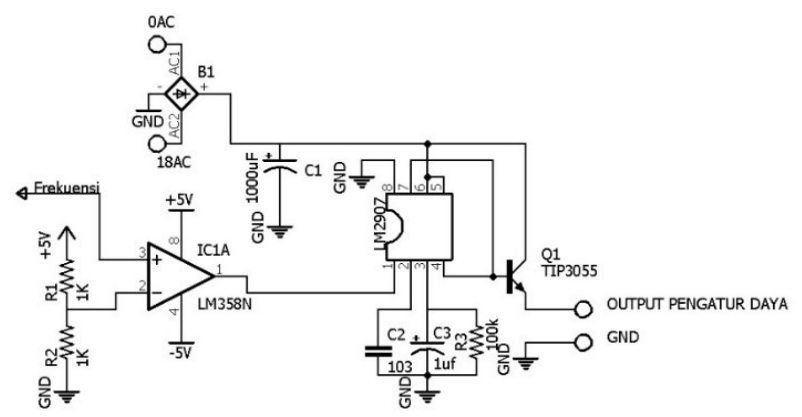

Fig 6. Power management circuit

\section{5) Inverter circuit}

An inverter circuit in Fig.7 is a circuit used to convert a 94 Volt DC voltage into a high voltage $A$. in the circuit there is the IRF740 MOSFET which is used for high voltage drivers.

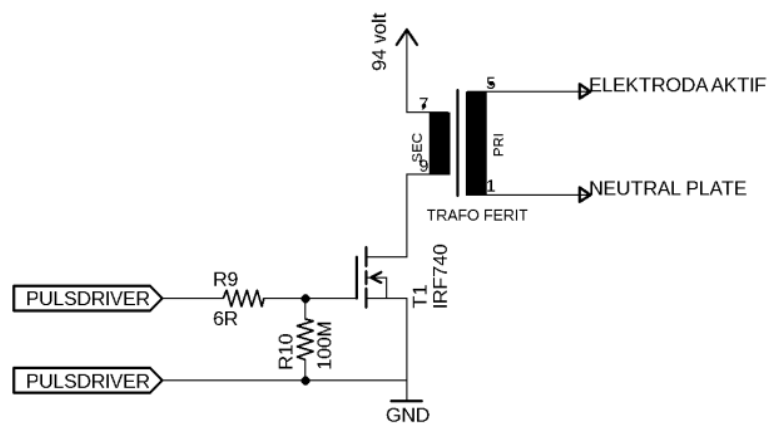

Fig 7. Inverter circuit

\section{RESULTS}

\section{A. Electrosurgery Design}

there is an image appearing outside Fig. 8 visible handpiece and footswitch as a switch to activate the existing mode and there is also a ground plate that functions as a media attached to the patient, then at Fig. 9 there are several circuits including a microcontroller, oscillator circuit, power regulator, pulse circuit control, power management, and inverter circuit.

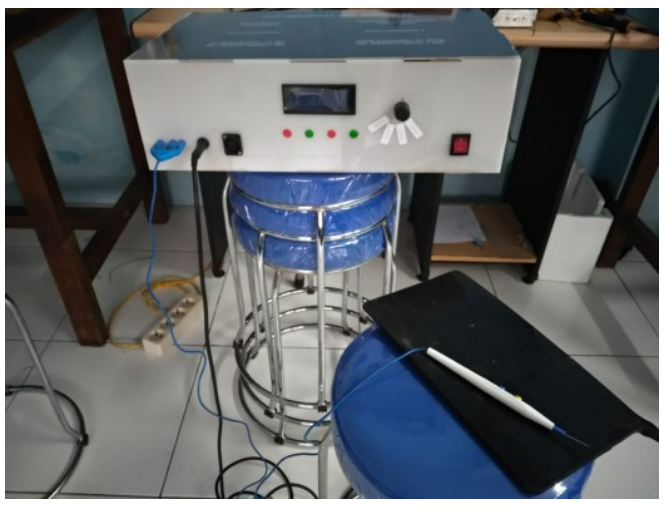

Fig 8. Electrosurgery Unit

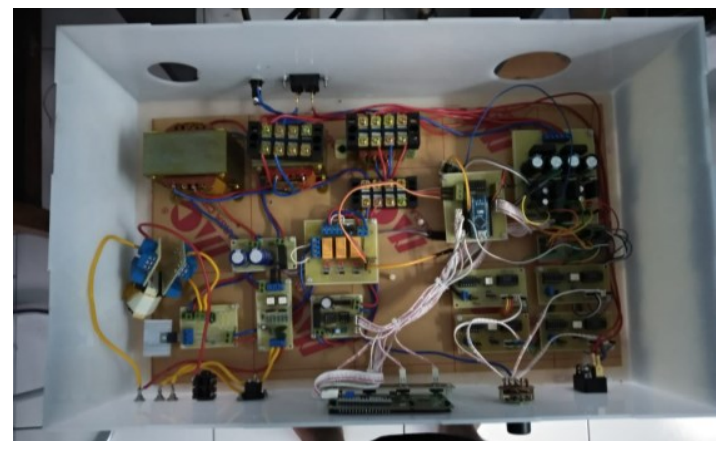

Fig 9. Circuit in electrosurgery unit

\section{B. Results program arduino of electrosurgery unit}

In this study using two control systems namely handpiece and footswitch.

Listing program 1, program initialization.

\#include $<$ Wire.h $>$

\#include < LiquidCrystal_I2C.h>

LiquidCrystal_I2C 1 cd $(0 \times 27,20,4)$;

int dutycycle $=6$;

int $\mathrm{dc}=255$;

int $\mathrm{ftv}=11$;

int mode,modedwn; 


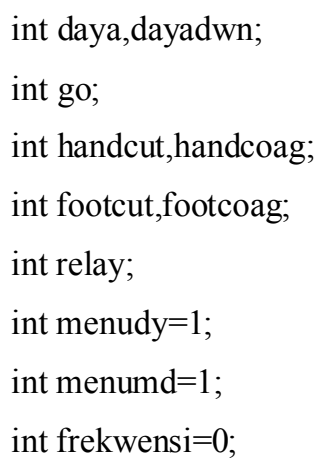

In the above program listing the initialization "int" is a numeric data type that is used when not dealing with fractions or decimals. "Include" as a library of I2C for LCD Character.

Listing program 2, program initial setting

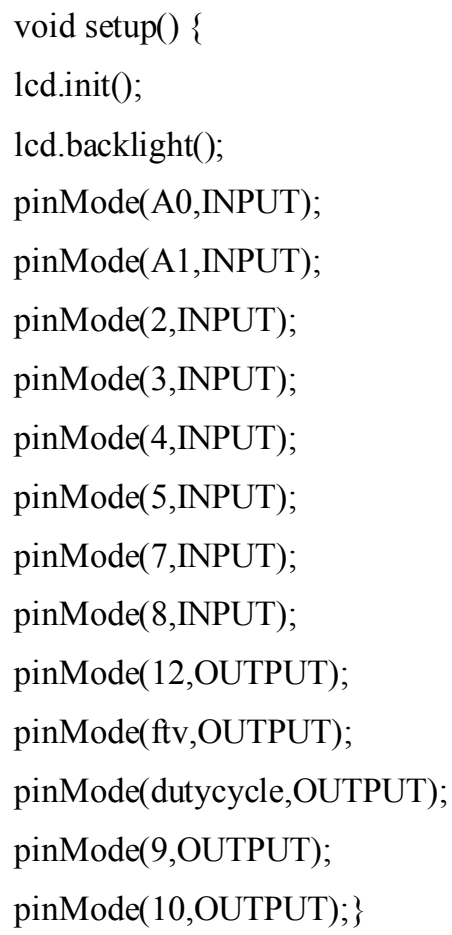

The program listing above is for setting the device setup, Pin2, Pin3, Pin4, Pin5, Pin7, Pin8, PinA0, PinA1 is set as input and Pin6, Pin9, Pin11, Pin12, as output.

Listing program 3, program power setting

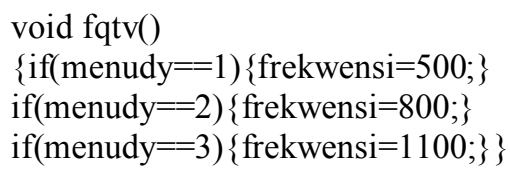

The program listing above is to set the amount of frequency that will be issued in pinftv according to the power selection, of which 500 for low, 800 for medium, and 1100 for high.

Listing program 4, program dutycycle setting.

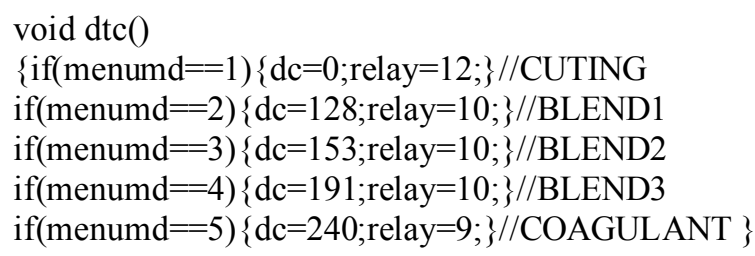

Listing program diatas merupakan untuk mengatur duty cycle. Pada lsting diatas untuk mengaktifkan dutycycle ketika salah satu kondisi terpenuhi. Maka PWM akan dikeluarkan sebesar nilai variable dc di pin dutycycle, dan pin relay akan mengeluarkan logika untuk mensaklar IC UL2003.

Listing program 5, program handswitch and footswitch.

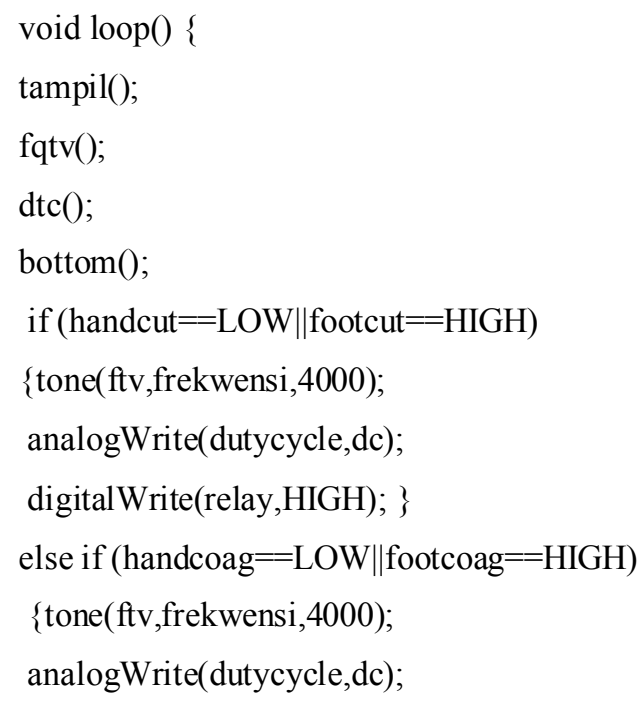

The program Listing above is the main program that governs when OUTPUT (Frequency, PWM, display, and relay logic) will be eject as well as the main program that runs everything. In this program all functions of the above program will be called for a continuous run, the program called is LCD programs, FTV, buttons, duty cycle which will then be issued when Handswitch or Footswitch in the press.

Listing program 6, program mode and power button.

void bottom ()\{

daya=digitalRead(4);

dayadwn=digitalRead(5);

$\operatorname{mode}=\operatorname{digitalRead}(7)$; 
modedwn=digitalRead(8);

handcut=digitalRead(2);

handcoag=digitalRead(3);

footcut $=$ digitalRead $(\mathrm{A} 0)$;

footcoag=digitalRead(A1);

The above program functions to read the logic of the button input and set the desired mode and power selection.

C. The measurement results of the frequency generator using a digital oscilloscope

Measurements are made at the oscillator output which is affected by the resistance value of the multiturn and capacitor. Measurement using an oscilloscope in TABLE I. with an error of $0.0016 \%$ and a graph deviation of Figure 10 is 1.14 . and in figure 11 you can see the oscilloscope display with square wave and $250 \mathrm{Khz}$ frequency.

TABLE I. MEASURMENT TABLE OF 250KHZ OSCILLATOR OUTPUT

\begin{tabular}{|c|c|}
\hline \multicolumn{2}{|c|}{ Oscillator circuit } \\
\hline Measurement & Oscilloscope Display (Khz) \\
\hline 1. & 250 \\
2. & 249 \\
3. & 252 \\
4. & 251 \\
5. & 250 \\
\hline Mean & $\mathbf{2 5 0 . 4}$ \\
\hline
\end{tabular}
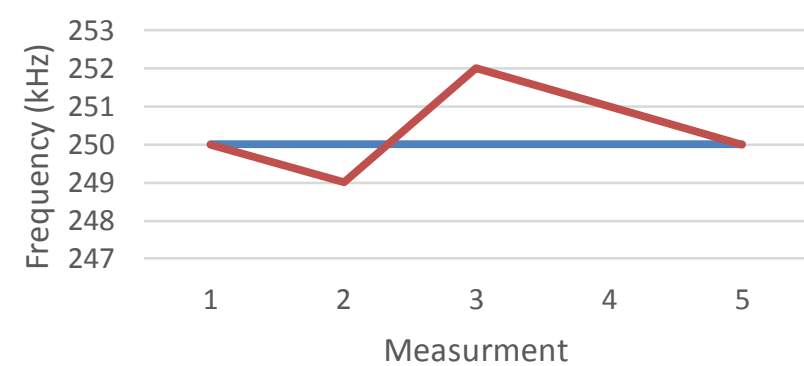

$\longrightarrow$ Setting Reading

Fig 10. Frequency Output

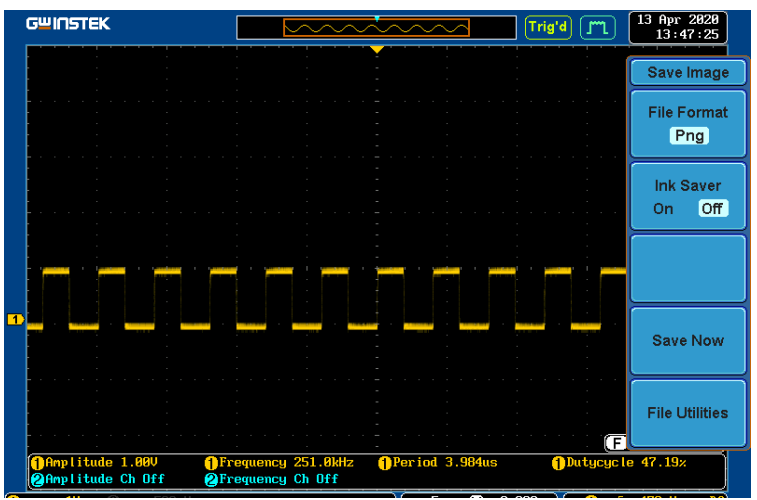

Fig 11. Frequency output measurement Digital Osilloscope

\section{Measurement on the module}

The voltage that is read on the digital oscilloscope on TABLE 2 is cutting with the voltage setting at low power being $170 \mathrm{~V}$, medium $180 \mathrm{~V}$ and high $190 \mathrm{~V}$ so that the resulting error can be seen above, on TABLE 3 is blend mode 1 with setting voltage at low power $80 \mathrm{~V}$, medium $90 \mathrm{~V}$, and $100 \mathrm{~V}$ high so that the resulting error can be seen in the table above, and the last in TABLE 4 is blend mode 2 with the voltage setting at low power is $80 \mathrm{~V}$, medium $90 \mathrm{~V}$ and high $100 \mathrm{~V}$, so that the error obtained as shown in the table above.

TABLE II. MEASUREMENT ELECTROSURGERY UNIT MODE CUTTING

\begin{tabular}{|c|c|c|}
\hline \multicolumn{3}{|c|}{ INPUT INVERTER } \\
\hline POWER & Voltage & Error (\%) \\
\hline LOW & $164.4 \mathrm{~V}$ & 2.88 \\
MEDIUM & $177 \mathrm{~V}$ & 3.03 \\
HIGH & $189.8 \mathrm{~V}$ & 2.86 \\
\hline
\end{tabular}

TABLE III. MEASUREMENT ELECTROSURGERY UNIT MODE BLEND 1

\begin{tabular}{|c|c|c|}
\hline \multicolumn{3}{|c|}{ INPUT INVERTER } \\
\hline POWER & Voltage & Error (\%) \\
\hline LOW & $83.6 \mathrm{~V}$ & 0.84 \\
MEDIUM & $91.6 \mathrm{~V}$ & 0.83 \\
HIGH & $104.8 \mathrm{~V}$ & 0.81 \\
\hline
\end{tabular}

TABLE IV. MEASUREMENT ELECTROSURGERY UNIT MODE BLEND 2

\begin{tabular}{|c|c|c|}
\hline \multicolumn{3}{|c|}{ INPUT INVERTER } \\
\hline POWER & Voltage & Error (\%) \\
\hline LOW & $82.8 \mathrm{~V}$ & 0.83 \\
MEDIUM & $93.6 \mathrm{~V}$ & 0.85 \\
HIGH & $105 \mathrm{~V}$ & 0.81 \\
\hline
\end{tabular}




\section{DISCUSSION}

The results of electrosurgery research with blend 1 , and blend 2 modes can be seen in TABLE 3 and TABLE 4 where it can be seen that the error value is less than $1 \%$, for TABLE 2 mode cutting the error value is less than $3 \%$, it means that the use of power settings and modes used are running well, in this study using a frequency to voltage converter circuit, a pulse regulator circuit, a power regulator circuit and also a frequency generator that produces an output of $250 \mathrm{Khz}$, and this frequency generator circuit as can be seen in TABLE 1 the error obtained is less than $1 \%$.

Albert and Webster pada tahun 2000[20] melakukan penelitian yang serupa dengan memanfaatkan generator frekuensi, sebgaiamana mengamati perubahan terhadap jaringan dengan daya yang diberikan. dan pada penelitian kali ini menggunakan pengaturan daya low, medium, dan high serta ada beberapa mode tambahan seperti blend 1, dan blend 2 .

In practice the use of power settings and correct selection of modes can minimize unwanted tissue damage during surgery, but the weakness in this study is still not using power settings with predetermined values.

\section{CONCLUSION}

In this study aims to make power settings and also several modes to minimize tissue damage during surgery, the power settings applied in this study are good enough to produce an error value of less than $1 \%$ for blend 1 and blend 2,but cutting mode error value less than $3 \%$, in this study can also make a simple oscillator circuit which can produce high frequencies, all modules can be controlled using footswitch and handswitch to cut, in this study the power settings used are three types of low, medium, and high which can be applied to several cutting, blend 1 and blend 2 modes. In short this study illustrates the difference in the signal produced in each mode due to the use of different dutycycle in each mode, and also the effect on power settings. For the development that can be done in subsequent studies is the addition of more modes and also the power that can be determined with the appropriate value.

\section{REFERENCES}

[1] N. Aggarwal, K. Ahuja, N. Pal, R. Pannu, and V. Berwal, "Review Article Electrosurgery : Welcome Part of Modern Surgery," ISSN:24542288, vol. 3, no. 3037, p. 9, 2017.

[2] R. Fish and L. Geddes, "Educación Popular en la elaboración de materiales para capacitación en TICs para el desarrollo social," ISSN:1937-5719, pp. 407-421, 2009.

[3] S. T. Vedbhushan and M. A. Mulla, "Surgical Incision by High Frequency Cautery," Assoc. Surg. India, p. 4, 2012.

[4] J. Sunardi et al., "Rancang Bangun Pisau Bedah Listrik Dengan Frekuensi $450 \mathrm{Khz}$ ( Esu )," Semin. Nas. SDM Teknol. NUKIR VII, no. November, pp. 600-604, 2011.

[5] M. G. Munro, "The SAGES Manual on the Fundamental Use of Surgical Energy (FUSE)," IEEE Syst. J. 10.1007/978-1-4614-2074-3, p. 7, 2012.

[6] D. E. Azagury, Book Review: The SAGES Manual on the Fundamental Use of Surgical Energy (FUSE), vol. 20, no. 3. 2013.
[7] A. K. Ward, C. M. Ladtkow, and G. J. Collins, "Material removal mechanisms in monopolar electrosurgery," Annu. Int. Conf. IEEE Eng. Med. Biol. - Proc., pp. 1180-1183, 2007.

[8] W. M. Honig, "The Mecanism of cutting in Electrosurgery," IEEE Trans. Biomed. Eng., no. January, pp. 58-62, 1975.

[9] J. E. Sebben, "Cutting Current and Cutaneous," dermatology Surg. Univ. Calif., vol. 1, pp. 29-32, 1988.

[10] D. L. Carr-Locke and J. Day, "Principles of Electrosurgery," Success. Train. Gastrointest. Endosc., pp. 125-134, 2011.

[11] B. A. W, I. A. St, and D. Sawitri, "Analisa keandalan, Safety Dan ketidakpastian electrosurgical unit," ITS - Undergrad., pp. 1-9, 2010.

[12] I. Alkatout, T. Schollmeyer, and N. A. Hawaldar, "Principles and Safety Measures of Electrosurgery in Laparoscopy," Sci. Pap., no. I, pp. 130$139,2012$.

[13] S. H. A. M. chasen; A. M. Miller, "Electrosurgery Unit And Instrument," United States Pat., p. 7, 1972.

[14] V. Dafinescu, V. David, and A. Tutuianu, "Electromagnetic Emissions due to Electrosurgery," Int. Conf. Expo. Electr. Power Eng. (EPE 2012), vol. 20, no. Epe, pp. 25-27, 2012.

[15] K. Gallagher and J. Miles, "Electrosurgery," 2010 ELsevier Ltd., no. 1, pp. 70-72, 2010.

[16] F. J. Pettersen, T. Martinsen, J. O. Høgetveit, Ø. G. Martinsen, and A. Model, "Unintentional heating at implants when using electrosurgery," pp. 5805-5808, 2015.

[17] M. Ali Sajjadian; Glenn Isaacson, "ELECTROSURGERY IN THE HEAD AND NECK," Departemenrt Otorhinolaryngol. Temple Univ. Childern's Med. Cent., no. 107, pp. 254-261, 1998.

[18] M. S. Tuleimat, "The Electrosurgery : - A Story of Controversies and Discrepancies," IEEE - 2010 Int. Conf. Bioinforma. Biomed. Technol., pp. 356-359, 2010.

[19] D. V Palanker, A. Vankov, and P. Huie, "Electrosurgery With Cellular Precision," IEEE Trans. Biomed. Eng., vol. 55, no. 2, pp. 838-841, 2008.

[20] M. Albert, J. G. Webster, T. Medical, A. John, and J. Wiley, "Electrosurgical Generator And System," United States Pat., no. 19, p. 20, 2000.

[21] R. J. Podhajsky, K. D. Johnson, and J. Case, "System And Method For Otput Control Of Electrosurgical Generator," Pat. Apl. Pyblication, vol. 1 , no. 19, p. $8,2009$. 